\title{
PERAN MEKANISME CORPORATE GOVERNANCE DALAM MEMITIGASI AGENCY COSTS
}

\author{
Stephen Prabawa Haryanto, Johan Yanto \\ Sekolah B is nis dan Ekonomi - Unive rsitas Prasetiya Mulya \\ BSD City Kavling Edutown I.1 , Jl. BSD Raya Utama, BSD City, Tangerang 15339
}

Keywords :

agency cost, board of commissioner size, ownership concentration, proportion of independent commissioner, and audit committee size

\section{Kata Kunci :}

agency costs, ukuran dewan ko mis aris, ownership concentration, proporsi ko misaris independen, dan ukuran komite audit

Cores ponding Author: stephenprbwa@gmail.com

\begin{abstract}
The purpose of this research is to evaluate the impact of ownership concentration, board of commissioner size, proportion of independent commissioner and audit committee size on agency costs in Indonesia. The sample used in this study consists of 263 non financial firms listed in Indonesian Stock Exchange during the period of 2010 - 2014. According to this finding, the best mechanism to mitigate agency costs proxied by asset turnover ratio is audit committee size. As the number of audit committee increased, the asset turnover ratio will also increase thus indicating that management is efficiently using the company's assets. When proxied by selling, general and administrative expense, ownership concentration, which measured by the percentage of shares held by majority become the better mechanism. It denotes that having an ownership concentration in a company could minimize agency costs as majority has power to control management.
\end{abstract}

\section{SARI PATI}

Penelitian ini bertujuan untuk menguji pengaruh ownership concentration, ukuran dewan komisaris, proporsi komisaris independen dan ukuran komite audit terhadap agency costs. Sampel dalam penelitian ini adalah 263 perusahaan non-financial yang terdaftar di Bursa Efek Indonesia selama periode 2010 - 2014. Hasil pengujian menunjukkan bahwa ukuran komite audit merupakan mekanisme terbaik dalam memitigasi agency costs dengan proksi rasio perputaran aset. Semakin bertambahnya jumlah anggota komite audit maka rasio perputaran aset akan meningkat dan mengindikasikan bahwa manajemen menggunakan aset perusahaan dengan efisien. Kemudian ketika menggunakan proksi biaya selling, general and administrative, ownership concentration yang diukur menggunakan persentase kepemilikan saham oleh mayoritas menjadi mekanisme yang paling baik. Hal itu menunjukkan bahwa ketersediaan konsentrasi kepemilikan dapat meminimalis ir agency costs karena pemegang saham mayoritas memiliki kekuatan untuk mengendalikan manajemen. 


\section{saki}

Studi Akuntansi \& Keuangan Indonesia

\section{Pendahuluan}

Dalam mencapai tujuan yang telah ditetapkan maka perusahaan memerlukan tata kelola yang baik untuk mengawasi hal tersebut. Namun di negara berkembang, perusahaan cenderung memiliki tata kelola dan efisiensi informasi yang lemah serta piramida struktur kepemilikan yang terkonsentrasi (Kumar \& Tsetsekos, 1999). Kondisi itu memungkinkan timbulnya masalah keagenan di dalam perusahaan. Menurut Jensen dan Meckling (1976) masalah keagenan merupakan perbedaan kepentingan antara agent dengan principal dimana agent berupaya memenuhi kepentingannya sendiri, dalam hal ini agent mewakili principal untuk menjalankan perusahaan.

Kemungkinan terjadinya masalah keagenan di dalam perusahaan perlu untuk dimitigas i sehingga kepentingan masing-masing pihak dapat terpenuhi. Menurut Shleifer dan Vishny (1997) corporate governance dapat menjadi mekanisme untuk meminimalisir masalah keagenan karena menahan manajer untuk mengambil keputusan yang menguntungkan diri sendiri dan memberi perlindungan bagi pemegang saham minoritas. Terkait dengan mekanisme tersebut, organ-organ di dalam perusahaan seperti dewan direksi, dewan komisaris, komisaris independen dan komite pendukung memainkan peran penting agar pelaksanaan tata kelola menjadi efektif (Komite Nasional Kebijakan Governance, 2006). Menurut Florackis (2008) ukuran dari anggota dewan mempengaruhi efektivitasnya sebagai mekanisme corporate governance sehingga semakin bertambahnya jumlah anggota maka memiliki kekuatan yang lebih dibandingkan jumlah anggota yang sedikit.

Beberapa penelitian mengenai ukuran dewan komisaris, proporsi komisaris independen dan ukuran komite audit telah dilakukan. Sanjaya dan Christianti (2012) menemukan bahwa ukuran dewan komisaris dan proporsi komisaris independen dapat meminimalisir biaya keagenan. Krisnauli dan Hadiprajitno (2014) menemukan hasil sejenis untuk kedua variabel tersebut yaitu dapat meminimalisir biaya keagenan namun ukuran komite audit tidak berpengaruh signifikan. Surjawati, Rossyati dan Widowati (2015) menemukan bahwa proporsi komisaris independen dan ukuran komite audit tidak berpengaruh signifikan. 


\section{saki}

Studi Akuntansi \& Keuangan Indonesia

Hasil penelitian Wijayati (2015) menunjukkan ukuran dewan komisaris tidak berpengaruh signifikan. Di negara maju, penelitian dilakukan oleh Kusnadi (2003) di Singapura dan menemukan bahwa ukuran dewan tidak dapat mengurangi biaya keagenan sedangkan ukuran komite audit dapat meminimalisir biaya keagenan. Singh dan Davidson (2003) menemukan bahwa ukuran dewan tidak dapat meminimalisir biaya keagenan pada perusahaan di Amerika.

Selain mekanisme tata kelola yang telah disebutkan, terdapat faktor lain yang dapat digunakan untuk meminimalisir masalah keagenan yaitu ownership concentration. Menurut Gugler dan Yurtoglu (2003) kepemilikan terkonsentrasi atau dalam hal ini pemegang saham mayoritas memiliki kemampuan mengendalikan manajemen sehingga mengurangi kemungkinan terdapat perbedaan kepentingan antara agent dan principal.

Penelitian mengenai ownership concentration telah dilakukan oleh beberapa peneliti. Sarwar dan Khan (2015) menemukan bahwa ownership concentration dapat meminimalisir biaya keagenan pada perusahaan di Pakistan. Hasil serupa dikemukakan oleh Florackis (2008) yaitu ownership concentration dapat mengurangi biaya keagenan pada perusahaan di Inggris. Namun Singh dan Davidson (2003) di Amerika menemukan hasil berbeda yaitu ownership concentration tidak memiliki pengaruh signifikan. Penelitian sejenis di Indonesia yang dilakukan oleh Hadiprajitno (2013) menunjukkan hasil yaitu ownership concentration tidak berpengaruh signifikan terhadap biaya keagenan.

Karena masih terdapat inkonsistensi hasil penelitian dan juga masih terbatasnya penelitian mengenai ownership concentration, ukuran dewan komisaris, proporsi komisaris independen dan ukuran komite audit terhadap agency costs menjadikan motivasi untuk melakukan penelitian ini. Penggunaan sektor penelitian yang lebih besar yaitu sektor non keuangan serta periode observasi 5 tahun diharapkan dapat menjadi kontribusi dari penelitian ini. Penelitian hanya difokuskan pada biaya keagenan dengan proksi rasio perputaran aset dan biaya selling, general and administrative.

Berdasarkan latar belakang yang telah diuraikan di atas, penulis tertarik untuk meneliti pengaruh ownership concentration, ukuran dewan komisaris, proporsi komisaris independen dan ukuran komite audit terhadap agency costs pada perusahaan non keuangan yang terdaftar di Bursa Efek Indonesia selama 


\section{saki}

Studi Akuntansi \& Keuangan Indonesia

periode 2010-2014. Struktur jurnal ini dibagi menjadi beberapa bagian yaitu bagian pertama pendahuluan, bagian kedua landasan teori, bagian ketiga metode penelitian, bagian keempat analisa dan pembahasan serta bagian kelima kesimpulan dan saran.

\section{Telaah Literatur dan Pengembangan Hipotesis}

Agency Theory

Menurut Jensen dan Meckling (1976) agency theory yaitu teori yang menjelaskan mengenai hubungan antara principal sebagai pemilik dengan agent sebagai pihak yang diberikan wewenang untuk menjalankan perusahaan. Akan tetapi dalam menjalankan tugasnya, agent dapat mengambil keputusan yang tidak sesuai dengan kepentingan principal terkait maksimalisasi keuntungan bagi principal. Jensen dan Meckling (1976) mengemukakan tiga tipe masalah keagenan yang mungkin terjadi yaitu: (1) Tipe 1, konflik antara principal (pemegang saham) dengan agent (manajer) karena terdapat perbedaan kepentingan; (2) Tipe 2, konflik antara pemegang saham mayoritas dengan pemegang saham minoritas karena terdapat perbedaan kekuatan terutama dalam pengambilan keputusan; (3) Tipe 3, konflik antara manajer dan pemegang saham dengan pihak ketiga dari luar perusahaan seperti pemberi pinjaman, auditor dan pemerintah karena terdapat syarat - syarat yang harus dipenuhi terkait pengawasan oleh pihak ketiga tersebut.

Lebih lanjut Jensen dan Meckling (1976) mengemukakan bahwa untuk memastikan agent mengambil keputusan sesuai dengan kepentingan principal maka dibutuhkan biaya - biaya sebagai berikut: (1) Bonding cost, merupakan biaya yang dikeluarkan principal untuk memastikan bahwa agent tidak mengambil tindakan yang merugikan principal atau sebagai jaminan ganti rugi jika hal tersebut terjadi; (2) Monitoring cost, merupakan biaya yang dikeluarkan principal untuk melakukan pengawasan atas perilaku agent termasuk pengendaliannya; (3) Residual loss, merupakan kerugian yang mungkin dialami principal karena perbedaan keputusan yang diambil agent dengan keputusan yang seharusnya diambil untuk memaksimalkan kesejahteraan principal. 


\section{saki}

Studi Akuntansi \& Keuangan Indonesia

\section{Pengembangan Hipotesis}

\section{Ownership concentration}

Menurut Florackis (2008) salah satu cara untuk mengurangi masalah keagenan yaitu menerapkan konsentrasi kepemilikan karena pemegang saham harus mengawasi manajer dalam menjalankan perusahaan. Konsentrasi kepemilikan pada pemegang saham dengan jumlah yang sedikit dapat mempermudah pengambilan keputusan dibandingkan jika kepemilikan dibagi ke banyak pihak, terutama pemegang saham dengan kepemilikan 51\% atau lebih dapat mengurangi masalah keagenan karena dapat mengendalikan jalannya perusahaan sehingga mampu memenuhi kepentingannya sebagai pemegang saham (Shleifer \& Vishny, 1997).

Shleifer dan Vishny (1997) mengemukakan bahwa konsentrasi kepemilikan berupa pemegang saham dengan kepemilikan 51\% atau lebih dapat meminimalis ir biaya keagenan karena pemegang saham tersebut memiliki hak untuk mengendalikan perusahaan terutama dalam pengambilan keputusan. Beberapa penelitian juga menunjukkan hasil sejenis (Florackis, 2008; Kusnadi, 2003; Sarwar \& Khan, 2015) sehingga dapat dirumuskan hipotes is sebagai berikut :

H1a : Ownership concentration memiliki pengaruh signifikan positif terhadap agency costs dengan proksi rasio perputaran aset.

H1b : Ownership concentration memiliki pengaruh signifikan negatif terhadap agency costs dengan proksi biaya selling, general and administrative.

\section{Ukuran Dewan Komisaris}

Menurut Kiel dan Nicholson (2003) ukuran dewan memiliki hubungan dengan masalah keagenan karena dengan memiliki anggota yang banyak dapat meningkatkan pengawasan atas kinerja manajemen sehingga meminimalisir potensi terjadinya masalah keagenan. Truong dan Heaney (2013) menyatakan bahwa dengan bertambahnya jumlah anggota dewan maka pengawasan menjadi lebih baik dalam mengurangi masalah keagenan karena masing-masing anggota memiliki kontribusi kemampuan yang berbeda. 


\section{saki}

Studi Akuntansi \& Keuangan Indonesia

Di Indonesia, anggota dewan menggunakan sistem two-tier sesuai Undang - Undang Nomor 40 Tahun 2007 tentang Perseroan Terbatas (Presiden Republik Indonesia \& Dewan Perwakilan Rakyat [DPR], 2007) serta Peraturan Otoritas Jasa Keuangan [OJK] Nomor 33/POJK.04/2014 (OJK, 2014) yang dibagi menjadi dua yaitu dewan direksi dan dewan komisaris. Dewan komisaris dalam UU No. 40 Tahun 2007 dinyatakan memiliki tugas untuk mengawasi jalannya kegiatan operasional dan mengawasi kebijakan yang diambil Direksi serta memberi pendapat sesuai dengan tujuan perusahaan (Presiden Republik Indonesia \& DPR, 2007). Sesuai aturan OJK No. 33/POJK.04/2014, dewan komisaris beranggotakan minimum dua dengan salah satu anggota ditetapkan sebagai presiden komisaris dan anggota lainnya sebagai komisaris independen (OJK, 2014).

Semakin besar jumlah anggota dewan maka dapat meminimalisir masalah keagenan karena masing - masing anggota dapat memberikan kontribusi kemampuan dan pengalaman yang berbeda satu sama lain (Truong \& Heaney, 2013). Florackis (2008) mengemukakan bahwa jumlah anggota dewan mempengaruhi efektivitasnya sebagai mekanisme corporate governance. Berdasarkan hal tersebut maka dapat diusulkan hipotes is sebagai berikut :

H2a. Ukuran dewan komisaris memiliki pengaruh signifikan positif terhadap agency costs dengan proksi rasio perputaran aset.

H2b. Ukuran dewan komisaris memiliki pengaruh signifikan negatif terhadap agency costs dengan proksi biaya selling, general and administrative.

\section{Proporsi Komisaris Independen}

Mengacu kepada peraturan OJK No. 33/POJK.04/2014, komisaris independen harus terdapat dalam dewan komisaris dimana jika anggota dewan komisaris berjumlah dua maka salah satunya ditetapkan sebagai komisaris independen dan apabila jumlah dewan komisaris melebihi dua maka minimum 30\% harus diangkat menjadi komisaris independen (OJK, 2014). Menurut Krisnauli dan Hadiprajitno (2014) komisaris independen berfungsi untuk melakukan pengawasan terkait tata kelola 


\section{saki}

Studi Akuntansi \& Keuangan Indonesia

perusahaan karena menjadi perwakilan dari pemegang saham sebagai pihak independen sehingga mengikuti kepentingan pemegang saham.

Komisaris independen melakukan pengawasan atas kinerja manajemen terkait tata kelola perusahaan serta menjadi wakil dari pemegang saham dan kepentingannya (Krisnauli \& Hadiprajitno, 2014). Tingginya jumlah komisaris independen dapat menjadi alat pengawasan yang memainkan perananan penting dalam mengendalikan masalah keagenan (Gul, Sajid, Razzaq \& Afzal., 2012; SetiaAtmaja, Haman \& Tanewski, 2011). Mengacu kepada hal tersebut maka dapat dirumuskan hipotesis :

H3a. Proporsi komisaris independen memiliki pengaruh signifikan positif terhadap agency costs dengan proksi rasio perputaran aset.

H3b. Proporsi komisaris independen memiliki pengaruh signifikan negatif terhadap agency costs dengan proksi biaya selling, general and administrative.

\section{Ukuran Komite Audit}

Berdasarkan peraturan OJK No. 55/POJK.04/2015, komite audit wajib dibentuk oleh perusahaan terbuka untuk membantu dan meningkatkan efektivitas tugas dewan komisaris dimana minimum anggota terdiri dari tiga, satu anggota berasal dari komisaris independen dan anggota lainnya berasal dari luar perusahaan (OJK, 2015). Menurut Surjawati et al. (2015) komite audit berfungsi untuk memastikan kredibilitas penyusunan laporan keuangan dan menjaga pelaksanaan tata kelola perusahaan yang baik.

Menurut Surjawati et al. (2015) komite audit dapat menjaga mekanisme pengawasan perusahaan terutama pelaksanaan tata kelola dan juga menjaga kredibilitas penyusunan laporan keuangan. Semakin tinggi jumlah komite audit dapat meminimalisir masalah keagenan karena pengawasan menjadi lebih efektif (Ghosh et al., 2010; Yasser, Entebang \& Mansor, 2011). Oleh karena itu dapat dirumuskan hipotesis sebagai berikut :

H4a. Ukuran komite audit memiliki pengaruh signifikan positif terhadap agency costs dengan proksi rasio perputaran aset. 


\section{saki}

Studi Akuntansi \& Keuangan Indonesia

H4b. Ukuran komite audit memiliki pengaruh signifikan negatif terhadap agency costs dengan proksi biaya selling, general and administrative.

\subsection{Kerangka Penelitian}

Mengacu kepada penelitian Florackis (2008), Kusnadi (2003) serta Sarwar dan Khan (2015), ownership concentration dapat digunakan untuk meminimalis ir biaya keagenan. Tidak hanya itu, anggota dewan di perusahaan juga dapat mengurangi biaya keagenan (Truong \& Heaney, 2013). Agar semakin efektif dalam meminimalis ir biaya keagenan maka diperlukan komisaris independen dan juga komite audit terutama untuk membantu pengawasan (Setia-Atmaja et al., 2011; Ghosh et al. 2010). Oleh karena itu dapat dirumuskan kerangka penelitian sebagai berikut:

\section{Gambar 1. Kerangka Penelitian}

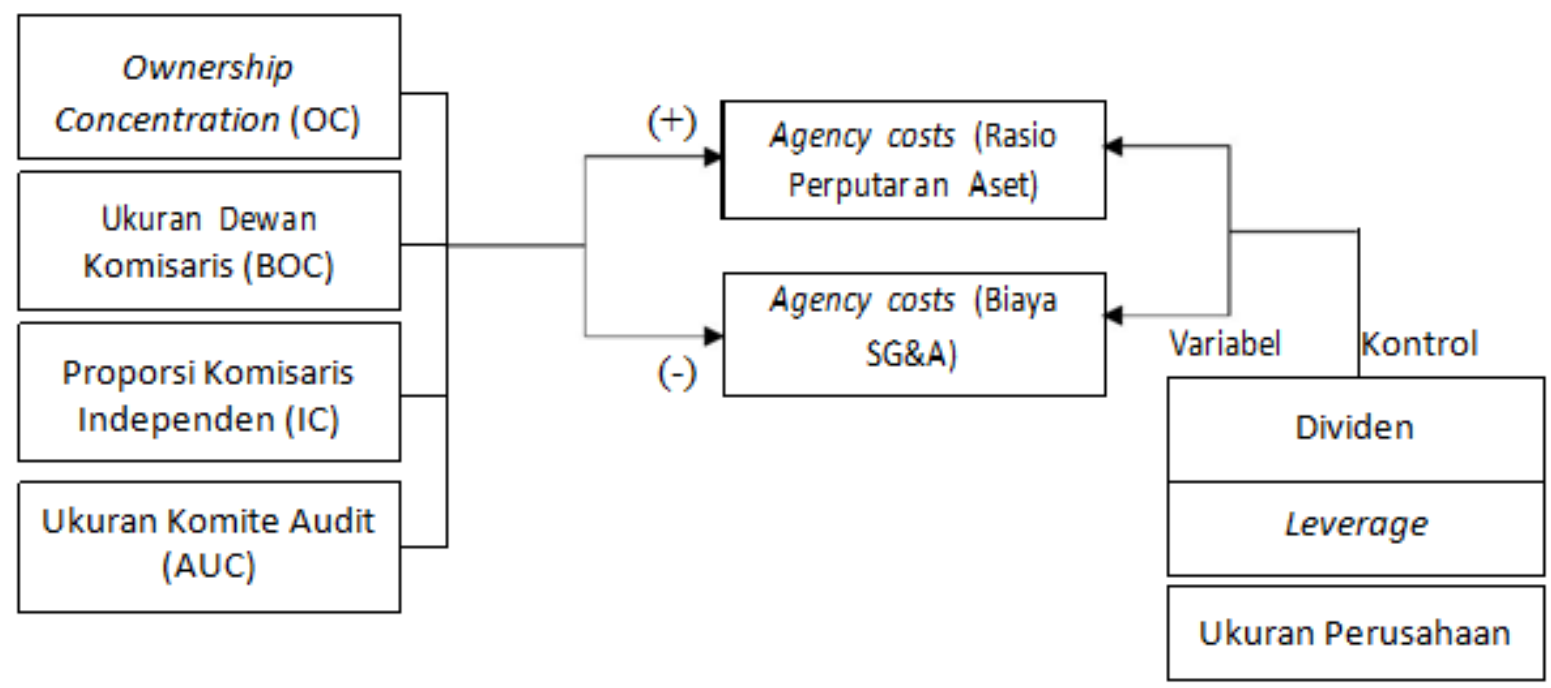

\section{Metode Penelitian}

\section{Data dan Sampel}

Penelitian ini menggunakan sampel berupa seluruh perusahaan non keuangan yang terdaftar di Bursa Efek Indonesia selama periode 2010 - 2014. Penelitian ini menggunakan unbalanced panel data 


\section{saki}

Studi Akuntansi \& Keuangan Indonesia

dengan sumber data dari Bloomberg dan The Indonesia Capital Market Institute. Pemilihan sampel menggunakan teknik purposive sampling dengan kriteria - kriteria sebagai berikut:

1. Perusahaan publik yang terdaftar di Bursa Efek Indonesia.

2. Perusahaan publik yang bergerak di sektor non keuangan.

3. Perusahaan publik non keuangan yang memiliki kepemilikan mayoritas lebih dari $50 \%$.

4. Perusahaan yang menggunakan mata uang Rupiah sebagai mata uang utama pencatatan laporan keuangan.

Dengan menggunakan criteria-kriteria di atas untuk mengeliminasi sampel, didapatkan jumlah sampel akhir sebanyak 263 perusahaan dengan total observasi 852 selama 5 tahun periode penelitian. Perusahaan pada sektor keuangan tidak diikutsertakan karena memiliki perlakuan keuangan dan akuntansi yang khusus (Sarwar \& Khan, 2015).

\section{Variabel Penelitian}

Variabel dependen dalam penelitian ini yaitu agency costs dengan variabel independen berupa ownership concentration, ukuran dewan komisaris, proporsi komisaris independen dan ukuran komite audit. Selain itu terdapat pula variabel kontrol yaitu dividen, leverage dan ukuran perusahaan. Tabel berikut menunjukkan variabel yang digunakan dalam penelitian beserta proksinya:

Tabel 1. Variabel Pe ne litian

\begin{tabular}{|c|l|l|}
\hline No. & \multicolumn{1}{|c|}{ Variabel } & \multicolumn{1}{c|}{ Proksi } \\
\hline 1. & Agency cost & Rasio asset turnover (ATO) \\
\hline & & Selling, general and admin is trative expense (SGA) \\
\hline 2. & Ownership concentration (OC) & $\begin{array}{l}\text { Persentase kepemilikan pemegang saham mayoritas lebih dari } \\
50 \%\end{array}$ \\
\hline 3. & Ukuran de wan komisaris (BOC) & Jumlah anggota dewan komisaris \\
\hline 4. & Proporsi ko mis aris independen (IC) & $\begin{array}{l}\text { Proporsi ko mis aris independen terhadap totao anggota dewan } \\
\text { komisaris }\end{array}$ \\
\hline 5. & Ukuran komite audit (AUC) & Jumlah anggota komite audit \\
\hline 6. & Leverage (DAR) & Debt-to-asset ratio = total debt/total asset \\
\hline 7. & Dividen (DPR) & Dividend-payout-ratio = dividend/net income \\
\hline 8. & Ukuran perusahaan (Log_TA) & Log Total asset \\
\hline
\end{tabular}

\section{Model Penelitian}




\section{saki}

Studi Akuntansi \& Keuangan Indonesia

Penelitian ini menggunakan model regresi linier berganda karena terdapat factor-faktor yang dapat mempengaruhi variabel terikat (Ghozali, 2005). Untuk menguji hipotesis mengenai pengaruh variabel independen terhadap agency costs maka model yang digunakan yaitu sebagai berikut:

Model 1:

$\mathrm{ATO}_{\mathrm{it}}=\alpha_{\mathrm{i}}+\beta_{1} \mathrm{OC}_{\mathrm{it}}+\beta_{2} \mathrm{BOC}_{\mathrm{it}}+\beta 3 \mathrm{IC} \_$it $+\beta_{4} \mathrm{AUC}_{\mathrm{it}}+\beta_{5} \mathrm{DAR}_{\mathrm{it}}+\beta_{6} \mathrm{DPR}_{\mathrm{it}}+\beta_{7} \mathrm{LOG}_{-} \mathrm{TA}_{\mathrm{it}}+\varepsilon_{\mathrm{it}}$

Model 2:

$\mathrm{SGA}_{\mathrm{it}}=\alpha_{\mathrm{i}}+\beta 1 \mathrm{OC}_{\mathrm{it}}+\beta_{2} \mathrm{BOC}_{\mathrm{it}}+\beta_{3} \mathrm{IC} \_$it $+\beta_{4} \mathrm{AUC} \_$it $+\beta_{5} \mathrm{DARit}+\beta_{6} \mathrm{DPRit}+\beta_{7} \mathrm{LOG}_{-} \mathrm{TA}_{\mathrm{it}}+\varepsilon \mathrm{it}$

\section{Analisa Dan Pembahasan}

Analisis Statistik Deskriptif

Berikut merupakan tabel statistic deskriptif untuk masing-masing variabel penelitian:

Tabel 2. Analis is Statis tik Deskriptif

\begin{tabular}{|c|c|c|c|c|c|}
\hline Variabel & Obs & Mean & Std. Dev. & Min. & Max. \\
\hline ATO & 852 & 1.02 & 0.82 & 0 & 5.65 \\
\hline S GA_ & 852 & 624.6531 & 1099.779 & 0.393 & 5000 \\
\hline OC__ $_{-}$ & 852 & 0.68 & 0.13 & 0.5 & 0.99 \\
\hline BOC_ & 852 & 4.25 & 1.79 & 2 & 12 \\
\hline IC_ & 852 & 0.4 & 0.1 & 0.2 & 0.8 \\
\hline AUC_ & 852 & 3.08 & 0.56 & 0 & 7 \\
\hline DAR & 852 & 0.22 & 0.21 & 0 & 1.1 \\
\hline DPR & 852 & 0.24 & 0.45 & -2.7 & 3.2 \\
\hline LOG_TA & 852 & 14.41 & 1.76 & 9.11 & 19.28 \\
\hline
\end{tabular}

Berdasarkan Tabel 2 di atas, variabel dependen agency costs menggunakan nama ATO karena menggunakan Asset Turnover sebagai proksi. Nilai mean ATO dari perusahaan nonkeuangan yang ada di 


\section{saki}

Studi Akuntansi \& Keuangan Indonesia

Indonesia yaitu sebesar 1.02. Jika melihat dari nilai minimum 0 hingga nilai maksimum 5.65 maka perusahaan dengan ATO sebesar nilai rata-rata masih kurang dalam menghasilkan revenue dengan menggunakan aset yang dimilikinya. Nilai mean SGA_ dari perusahaan nonkeuangan yang ada di Indonesia yaitu sebesar 624.653.1, dimana variabel ini tercatat dalam miliaran Rupiah, yang berarti ratarata perusahaan memiliki biaya SG\&A sebesar 624.653.1 miliar Rupiah.

Variabel ownership concentration menggunakan nama $\mathrm{OC}_{-}$dengan nilai mean sebesar 0.68 yang berarti rata- rata perusahaan nonkeuangan di Indonesia memiliki kepemilikan mayoritas sebesar 0.68 atau 68\%. Variabel dewan komisaris menggunakan nama BOC_ dengan mean sebesar 4.25 yang berarti ratarata perusahaan nonkeuangan di Indonesia memiliki jumlah anggota dewan komisaris sebanyak empat orang. Variabel komisaris independen menggunakan nama IC_dan memiliki mean sebesar 0.4 yang dapat diartikan bahwa rata-rata perusahaan nonkeuangan di Indonesia memiliki proporsi komisaris independen sebesar 40 persen. Variabel komite audit menggunakan nama $\mathrm{AUC}_{-}$dengan mean 3.08 yang dapat diartikan yaitu rata - rata perusahaan nonkeuangan di Indonesia memiliki tiga anggota yang tergabung di dalam komite audit.

Variabel leverage menggunakan nama DAR sesuai dengan proksi yang digunakan yaitu debt-toassets ratio. Nilai mean sebesar 0.22 yang berarti rata-rata perusahaan nonkeuangan di Indonesia hanya menggunakan hutang untuk membiayai asetnya sebanyak 22 persen. Variabel dividend menggunakan nama DPR sesuai dengan proksi yang digunakan yaitu dividend payout ratio. Nilai mean sebesar 0.24 yang berarti rata - rata perusahaan nonkeuangan di Indonesia membagikan dividen hanya sebesar 24 persen dari laba yang diperoleh. Variabel ukuran perusahaan menggunakan nama LOG_TA sesuai dengan proksi yang digunakan yaitu logaritme dari total asset. Nilai mean dari variabel ini sebesar 14.41 dengan standar deviasi sebesar 1.76 yang menunjukkan persebaran data dari mean tidak terlalu luas. Nilai minimum sebesar 9.11 terdapat pada PT Steady Safe Tbk dan nilai maksimum sebesar 19.28 dimiliki oleh PT Astra International Tbk.

\section{Uji Hipotesis}


Berikut merupakan hasil uji hipotes is yang dilakukan terhadap variabel dependen dengan proksi pertama yaitu rasio perputaran aset dengan model FE:

Tabel 6. Uji Hipotes is Model 1

\begin{tabular}{|c|c|c|c|c|}
\hline & & \multicolumn{3}{|c|}{$\begin{array}{l}\text { Nu mber of obs }=852 \\
\text { Nu mber of g roups }=231 \\
\text { Prob }>F=0.0000 \\
\text { within R-square }=0.1347\end{array}$} \\
\hline ATO & Coef. & Std. Err. & $\mathbf{t}$ & $\mathbf{P}>|\mathbf{t}|$ \\
\hline $\mathrm{OC}_{-}$ & -0.2567253 & 0.3060585 & -0.84 & 0.402 \\
\hline $\mathrm{BOC}_{-}$ & -0.010388 & 0.0082951 & -1.25 & 0.212 \\
\hline $\mathrm{IC}_{-}$ & -0.2949826 & 0.1014735 & -2.91 & $0.004 * * *$ \\
\hline $\mathrm{AUC}_{-}$ & 0.0442939 & 0.0090343 & 4.9 & $0.000^{* * *}$ \\
\hline DAR & -0.0977741 & 0.1128343 & -0.87 & 0.387 \\
\hline DPR & -0.0000694 & 0.0093824 & -0.01 & 0.994 \\
\hline LOG_TA & -0.3125982 & 0.0403895 & -7.74 & $0.000 * * *$ \\
\hline Constanta & 5.74292 & 0.4640346 & 12.38 & 0.000 \\
\hline \multicolumn{2}{|l|}{$\begin{array}{c}\text { *signifik an si } \\
\text { pada } 10 \%\end{array}$} & \multicolumn{2}{|l|}{$\begin{array}{c}* * \text { si gnifikansi } \\
\text { pada } 5 \%\end{array}$} & $\begin{array}{c}* * * \text { signifikansi } \\
\text { pada } 1 \%\end{array}$ \\
\hline
\end{tabular}

Berdasarkan tabel di atas, secara keseluruhan uji koefisien determinasi menunjukkan hasil within $R$-square sebesar 0.1358 yang berarti kemampuan variabel bebas dalam menjelaskan variabel terikat cukup kuat. Selain itu dengan uji F didapatkan nilai Prob > F sebesar 0.0000 yang dapat diartikan bahwa variabel bebas memiliki pengaruh signifikan terhadap variabel terikat. Berikut merupakan penjelasan untuk masing - masing uji hipotesis :

Variabel ownership concentration atau $\mathrm{OC}_{-}$memiliki koefisien negatif namun tidak berdampak signifikan terhadap variabel dependen sesuai uji $\mathrm{t}$ didapatkan hasil $\mathrm{P}>|\mathrm{t}|$ sebesar 0.402. Dengan hasil tersebut maka hipotesis 1a ditolak. Variabel ukuran dewan komisaris atau BOC_ memiliki koefisien negatif namun tidak berdampak signifikan terhadap variabel dependen sesuai dengan uji t didapatkan hasil $\mathrm{P}>|\mathrm{t}|$ sebesar 0.212. Hasil itu menjadikan hipotesis 2a ditolak. Variabel proporsi komisaris independen atau IC_ memiliki koefisien negatif dan berdampak signifikan terhadap variabel dependen 


\section{saki}

Studi Akuntansi \& Keuangan Indonesia

sesuai dengan uji t didapatkan hasil $\mathrm{P}>|\mathrm{t}|$ sebesar 0.004. Hal itu berarti semakin tinggi jumlah komisaris independen justru mengurangi efisiensi penggunaan aset dan tidak dapat meminimalisir biaya keagenan sehingga hipotesis 3a ditolak. Variabel ukuran komite audit atau AUC_ memiliki koefisien positif dan berdampak signifikan terhadap variabel dependen sesuai dengan uji $\mathrm{t}$ didapatkan hasil $\mathrm{P}>|\mathrm{t}|$ sebesar 0.0000. Hal itu dapat diartikan bahwa semakin bertambahnya jumlah anggota komite audit maka biaya keagenan dapat ditekan karena penggunaan aset semakin efisien. Oleh karena itu hipotes is 4a diterima.

Variabel leverage atau DAR memiliki koefisien negatif namun tidak berdampak signifikan terhadap variabel dependen sesuai dengan uji t yaitu didapatkan hasil $\mathrm{P}>|\mathrm{t}|$ sebesar 0.387 . Hasil tersebut sesuai dengan penelitian Henry (2010). Variabel dividend atau DPR memiliki koefisien negatif namun tidak berdampak signifikan terhadap variabel dependen sesuai dengan uji t yaitu didapatkan hasil $\mathrm{P}>|\mathrm{t}|$ sebesar 0.994. Hasil tersebut sesuai dengan penelitian Sarwar dan Khan (2015). Variabel ukuran perusahaan atau LOG_TA memiliki koefisien negatif dan berdampak signifikan terhadap variabel dependen sesuai dengan uji t yaitu didapatkan hasil $\mathrm{P}>|\mathrm{t}|$ sebesar 0.000 . Hasil ini sesuai dengan penelitian Sarwar dan Khan (2015).

\section{Uji Hipotesis Model 2}

Berikut merupakan hasil uji hipotesis yang dilakukan terhadap variabel dependen dengan proksi kedua yaitu biaya selling, general and administrative (SGA) dengan model FE:

\section{Tabel 7. Uji Hipotesis Model 2}

\begin{tabular}{|c|c|c|c|c|}
\hline & & \multicolumn{3}{|c|}{$\begin{array}{l}\text { Number of obs }=852 \\
\text { Nu mber of g roups }=231 \\
\text { Prob }>F=0.0000 \\
\text { within R-square }=0.1403\end{array}$} \\
\hline SGA_ & Coef. & Std. Err. & $\mathbf{t}$ & $\mathbf{P}>|\mathbf{t}|$ \\
\hline $\mathrm{OC}_{-}$ & -665.5661 & 273.6855 & -2.43 & $0.016^{* *}$ \\
\hline $\mathrm{BOC}_{-}$ & 33.8146 & 10.85047 & 3.12 & $0.002 * * *$ \\
\hline
\end{tabular}




\begin{tabular}{|c|c|c|c|l|}
\hline IC_ & 101.5737 & 106.7151 & 0.95 & 0.342 \\
\hline AUC_ & 50.8473 & 23.29689 & 2.18 & $0.03^{* *}$ \\
\hline DAR & 285.0185 & 57.44892 & 4.96 & $0.000^{* * *}$ \\
\hline DPR & -51.86057 & 23.94102 & -2.17 & $0.031^{* *}$ \\
\hline LOG_TA & 291.0695 & 29.89851 & 9.74 & $0.000^{* * *}$ \\
\hline Constanta & -3505.208 & 346.8787 & -10.10 & 0.000 \\
\hline $\begin{array}{c}* \text { signifik an si } \\
\text { pada 10\% }\end{array}$ & $\begin{array}{c}* * \text { signifi kansi } \\
\text { pada 5\% }\end{array}$ & $\begin{array}{c}* * * \text { signifikansi } \\
\text { pada } 1 \%\end{array}$ \\
\hline
\end{tabular}

Berdasarkan tabel di atas, secara keseluruhan uji koefisien determinasi menunjukkan hasil within $R$-square sebesar 0.1403 yang berarti kemampuan variabel bebas dalam menjelaskan variabel terikat cukup kuat. Selain itu dengan uji F didapatkan nilai Prob > F sebesar 0.0000 yang dapat diartikan bahwa variabel bebas memiliki pengaruh signifikan terhadap variabel terikat. Berikut merupakan penjelasan untuk masing - masing uji hipotesis :

Variabel ownership concentration atau OC_ memiliki koefisien negatif dan berdampak signif ikan terhadap variabel dependen sesuai uji t didapatkan hasil $\mathrm{P}>|\mathrm{t}|$ sebesar 0.016. Hasil tersebut berarti mekanisme konsentrasi kepemilikan atau dalam hal ini pemegang saham mayoritas lebih dari 50\% dapat digunakan untuk meminimalisir biaya keagenan sehingga hipotesis $1 \mathrm{~b}$ diterima. Variabel ukuran de wan komisaris atau BOC_ memiliki koefisien positif dan berdampak signifikan terhadap variabel dependen sesuai dengan uji t didapatkan hasil $\mathrm{P}>|\mathrm{t}|$ sebesar 0.002 . Hasil itu menunjukkan semakin meningkatnya jumlah anggota dewan komisaris maka biaya keagenan justru semakin besar sehingga hipotesis $2 \mathrm{~b}$ ditolak. Variabel proporsi komisaris independen atau IC_ memiliki koefisien positif namun tidak berdampak signifikan terhadap variabel dependen sesuai dengan uji $\mathrm{t}$ didapatkan hasil $\mathrm{P}>|\mathrm{t}|$ sebesar 0.342. Hal itu menjadikan hipotesis $3 \mathrm{~b}$ ditolak. Variabel ukuran komite audit atau AUC_ memiliki koefisien positif dan berdampak signifikan terhadap variabel dependen sesuai dengan uji t didapatkan hasil $\mathrm{P}>|\mathrm{t}|$ sebesar 0.03 . Hal itu dapat diartikan bahwa semakin bertambahnya jumlah anggota komite audit justru menyebabkan biaya keagenan mengalami peningkatan.

Variabel leverage atau DAR memiliki koefisien positif dan berdampak signifikan terhadap variabel dependen sesuai dengan uji t yaitu didapatkan hasil $\mathrm{P}>|\mathrm{t}|$ sebesar 0.000. Hasil itu sesuai dengan 


\section{saki}

Studi Akuntansi \& Keuangan Indonesia

penelitian Singh dan Davidson (2003). Variabel dividend atau DPR memiliki koefisien negatif dan berdampak signifikan terhadap variabel dependen sesuai dengan uji t yaitu didapatkan hasil $\mathrm{P}>|\mathrm{t}|$ sebesar 0.031. Hasil tersebut sesuai dengan penelitian Kusnadi (2003). Variabel ukuran perusahaan atau LOG_TA memiliki koefis ien positif dan berdampak signifikan terhadap variabel dependen sesuai dengan uji t yaitu didapatkan hasil $\mathrm{P}>|\mathrm{t}|$ sebesar 0.000. Hasil ini sesuai dengan penelitian Kusnadi (2003) serta Sarwar dan Khan (2015).

\section{Pembahasan}

Terjadinya masalah keagenan di dalam perusahaan dapat merugikan principal karena agen menggunakan sumber daya perusahaan untuk memenuhi kepentingannya tanpa memenuhi kepentingan principal. Hal itu menyebabkan principal harus mengeluarkan biaya untuk meminimalisir masalah keagenan yang disebut dengan agency cost. Guna mengurangi biaya keagenan tersebut, maka perusahaan dapat menerapkan corporate governance.

Setelah dilakukan uji hipotesis didapatkan hasil sebagai berikut; pertama, ownership consentration tidak memiliki pengaruh signifikan terhadap agency cost dengan proksi rasio perputaran asset sesuai dengan penelitian Singh dan Davidson (2003), namun memiliki pengaruh negatif signifikan terhadap agency cost dengan proksi SGA. Hal tersebut berarti ketersediaan konsentrasi kepemilikan dalam perusahaan atau dalam penelitian ini diukur menggunakan kepemilikan mayoritas dapat meminimalisir agency cost karena menurunkan biaya SGA. Ini sesuai dengan penelitian Florackis (2008), Kusnadi (2003).

Kedua, ukuran dewan komisaris tidak memiliki pengaruh signifikan terhadap agency costs dengan proksi rasio perputaran aset sesuai dengan penelitian Wijayati (2015) yang berarti bahwa jumlah anggota dewan komisaris yang banyak atau sedikit tetap tidak dapat mempengaruhi agency costs. Akan tetapi ukuran dewan komisaris berpengaruh signifikan positif terhadap agency costs dengan proksi SG\&A. Hasil tersebut menunjukkan bahwa bertambahnya anggota dewan komisaris tidak mampu untuk 


\section{saki}

Studi Akuntansi \& Keuangan Indonesia

meminimalisir biaya keagenan karena biaya SG\&A justru meningkat dan hal itu sesuai dengan penelitian Wijayati (2015).

Ketiga, proporsi komisaris independen memiliki pengaruh signifikan negatif terhadap agency costs dengan proksi rasio perputaran aset yang berarti peningkatan jumlah komisaris independen justru menurunkan efisiensi pemanfaatan aset. Hasil itu sesuai dengan penelitian Hadiprajitno (2013) namun ketika diukur terhadap proksi SG\&A, proporsi komisaris independen tidak memiliki pengaruh signif ikan seperti penelitian Surjawati et al. (2015) yang berarti berapapun jumlah komisaris independen tidak dapat mempengaruhi biaya keagenan.

Terakhir, ukuran komite audit memiliki pengaruh signifikan positif terhadap agency costs dengan proksi rasio perputaran aset yang menunjukkan bertambahnya jumlah komite audit menyebabkan penggunaan aset perusahaan semakin efisien sesuai dengan penelitian Kusnadi (2003). Akan tetapi ukuran komite audit tidak memiliki pengaruh signifikan terhadap agency costs dengan proksi SG\&A sesuai dengan penelitian Henry (2010), Krisnauli dan Hadiprajitno (2014) serta Surjawati et al. (2015) yaitu bertambahnya jumlah anggota komite audit tidak memiliki pengaruh terhadap biaya keagenan.

\section{Kesimpulan, Implikasi, dan Keterbatasan}

Penelitian ini menggunakan variabel dependen berupa agency costs dengan dua proksi yaitu rasio perputaran aset dan biaya selling, general and administrative. Variabel independen yang digunakan terdiri dari ownership concentration, ukuran dewan komisaris, proporsi komisaris independen dan ukuran komite audit. Selain itu terdapat pula variabel kontrol berupa leverage, dividend dan ukuran perusahaan. Setelah dilakukan uji hipotesis dapat ditarik kesimpulan bahwa tidak semua mekanisme corporate governance dapat digunakan untuk meminimalisir biaya keagenan di dalam perusahaan. Dengan menggunakan proksi rasio perputaran aset, mekanisme terbaik yaitu ukuran komite audit karena seiring bertambahnya jumlah anggota komite audit maka penggunaan aset perusahaan semakin efisien. Kemudian berdasarkan proksi SG\&A mekanisme yang paling baik yaitu ownership concentration 


\section{saki}

Studi Akuntansi \& Keuangan Indonesia

terutama dengan kepemilikan mayoritas karena pemegang saham mayoritas memiliki kekuatan untuk mengendalikan perusahaan dan mengawasi kinerja manajemen dengan lebih baik.

Penelitian ini diharapkan dapat memberikan tambahan pengetahuan terkait pengaruh ownership concentration, ukuran dewan komisaris, proporsi komisaris independen dan ukuran komite audit terhadap agency costs. Selain itu penelitian ini juga diharapkan dapat memberikan kontribusi bagi penelitianpenelitian selanjutnya sebagai bahan referensi.

Bagi investor dan calon investor diharapkan dapat memperhatikan kemungkinan terjadi masalah keagenan di dalam perusahaan. Jika terjadi masalah tersebut maka memerlukan biaya keagenan untuk meminimalisirnya. Salah satu cara untuk mengurangi biaya keagenan di dalam perusahaan yaitu dengan meningkatkan kepemilikan mencapai 50\% atau lebih. Namun karena berpotensi menimbulkan masalah keagenan tipe 2 maka sebagai pemegang saham mayoritas diharapkan tetap dapat mempertimbangkan kepentingan pemegang saham minoritas ketika mengambil keputusan. Selain itu perlu juga memperhatikan ukuran komite audit karena jumlahnya yang semakin banyak dapat meningkatkan efisiensi penggunaan aset sehingga menurunkan biaya keagenan.

Penelitian ini tentunya tidak luput dari keterbatasan. Pada penelitian ini, peneliti tidak dapat memperoleh penjabaran detail dari biaya general and administrative sehingga kurang dapat melihat kemungkinan agent mengkamuflasekan dana perusahaan sebagai biaya iklan untuk keuntungan pribadi. Penelitian selanjutnya diharapkan dapat memberikan penjabaran dari biaya general and administrative agar dapat melihat adanya potensi agent menggunakan dana perusahaan untuk keuntungan pribadi dengan mengkamuf lasekannya ke dalam biaya iklan.

\section{Daftar Pustaka}

Florackis, C. (2008). Agency costs and Corporate Governance Mechanisms: Evidence for UK Firms. International Journal of Managerial Finance, 4(1), 37-59.

Ghosh, A., Marra, A. \& Moon, D. (2010). Corporate Boards, Audit Committees, and Earn ings Management: Preand Post-SOX Evidence. Journal of Business Finance \& Accounting, 37(9) \& (10), 1145-1176.

Ghozali, I. (2005). Aplikasi Analisis Multivariate dengan Program SPSS. Semarang: Badan Penerbit Universitas Diponegoro. 


\section{saki}

Studi Akuntansi \& Keuangan Indonesia

Gugler, K. \& Yurtoglu, B.B. (2003). Corporate Governance and Dividend Pay-out Policy in Germany. European Economic Review, 47, 731-758.

Gul, S., Sajid, M., Razzaq, N. \& Afzal, F. (2012). Agency costs, Corporate Governance and Ownership Structure (The Case of Pakistan). International Joumal of Business and Social Science, 3(9).

Hadiprajitno, P.B. (2013). Struktur Kepemilikan, Mekanis me Tata Kelola Perusahaan, dan Biaya Keagenan di Indonesia (Studi Empirik pada Perusahaan di Bursa Efek Indonesia). Jurnal Akuntansi \& Auditing, 9(2), $97-127$.

Henry, D. (2010). Agency costs, Ownership Structure and Corporate Governance Compliance: A Private Contracting Perspective. Pacific-Basin Finance Journal, 18, 24-46.

Jensen, M.C. \& Meckling, W.H. (1976). Theory of Firm: Managerial Behavior, Agency Cost and Ownership Structure. Journal of Financial Economics, 3(4), 305-360.

Kiel, G.C. \& Nicholson, G.J. (2003). Board Composition and Corporate Performance: How the Australian Experience Informs Contrasting Theories of Corporate Governance. Corporate Governance: An International Review, 11(3), 189-205.

Komite Nasional Kebijakan Governance (2006). Indonesia's Code of Good Corporate Governance. Indonesia: Ko mite Nasional Kebijakan Governance.

Krisnauli \& Hadiprajitno, P.B. (2014). Pengaruh Mekan isme Tata Kelola Perusahaan dan Struktur Kepemilikan Terhadap Agency Cost (Studi Empiris pada Perusahaan Manufaktur yang Terdaftar di BEI Tahun 20102012). Diponegoro Journal of Accounting , 3(2), 1-13.

Kumar, P.C. \& Tsetsekos, G.P. (1999). The Differentiation of Emerging Equity Markets. Applied Financial Economics, 9, 443-453.

Kusnadi, Y. (2003). Corporate Cash Holdings and Corporate Governance Mechanisms. From http://papers.ssrn.com/sol3/papers.cfm?abstract id=479401 (Diakses pada 27 Agustus, 2016).

Lind, D.A., Marchal, W.G. \& Watthen, S.A. (2013). Statistical Techniques in Business \& Economics. Boston: McGraw-Hill/Irwin.

Otoritas Jasa Keuangan (2014). Peraturan Otoritas Jasa Keuangan Nomor 33/POJK.04/2014 . Indonesia: Lembaran Negara Republik Indonesia.

Otoritas Jasa Keuangan (2015). Peraturan Otoritas Jasa Keuangan Nomor 55/POJK.04/2015. Indonesia: Lembaran Negara Republik Indonesia.

Presiden Republik Indonesia \& Dewan Perwakilan Rakyat (2007). Undang - Undang Nomor 40 Tahun 2007 Tentang Perseroan Terbatas. Indonesia: Lembaran Negara Republik Indonesia.

Priyatno, D. (2014). SPSS 22: Pengolahan Data Terpraktis ( $1^{\text {st }}$ ed.). Yogyakarta: C.V. ANDI OFFSET.

Sanjaya, I.P.S. \& Christianti, I. (2012). Corporate Governance and Agency Cost: Case in Indonesia. $2^{\text {nd }}$ International Conference on Business, Economics, Management and Behavioral Sciences.

Sarwar, S. \& Khan, M.K. (2015). Ownership of Blockholders and Agency costs: Evidence from Pakistan. Scholars Journal of Economics, Business and Management, 2(4), 379-382.

Setia-Atmaja, L., Haman, J. \& Tanewski, G. (2011). The Role of Board Independence in Mitigating Agency Problem II in Australian Family Firms. The British Accounting Review, 43, 230-246

Shleifer \& Vishny (1997). A Survey of Corporate Governance. The Journal of Finance, 52(2), 737-738.

Singh, M. \& Davidson III, W.N. (2003). Agency costs, Ownership Structure and Corporate Governance Mechanisms. Journal of Banking \& Finance, 27, 793-816.

Surja wati, Rossyati \& Widowati, A.I. (2015). Corporate Governance, Struktur Kepemilikan dan Biaya Agensi (Pada Perusahaan LQ 45 Indonesia Tahun 2009-2011). Seminar Nasional Hasil Penelitian V.

Truong, T.T. \& Heaney, R. (2013). The Determinants of Equity Agency Conflicts Between Managers and Shareholders: Evidence from Australia. Journal of Multinational Financial Management, 23, 314-326.

Wijayati, F.L. (2015). Analisis Pengaruh Kepemilikan Manajerial, Kepemilikan Institusional, Ukuran Dewan Direksi, dan Ukuran Dewan Ko misaris Terhadap Biaya Keagenan. EBBANK, 6(2), 1-16.

Yasser, Q.R., Entebang, H. \& Mansor, S.A. (2011). Corporate Governance and Firm Performance in Pakistan: The Case of Karachi Stock Exchange (KSE)-30. Journal of Economics and International Finance, 3(8), 482491 